\title{
Iron-free and iron-saturated bovine lactoferrin inhibit survivin expression and differentially modulate apoptosis in breast cancer
}

\author{
Jessica A. Gibbons, Jagat R. Kanwar and Rupinder K. Kanwar ${ }^{*}$
}

\begin{abstract}
Background: Iron binding, naturally occurring protein bovine lactoferrin (bLf) has attracted attention as a safe anti-cancer agent capable of inducing apoptosis. Naturally, bLf exists partially saturated (15-20\%) with Fe ${ }^{3+}$ however, it has been demonstrated that manipulating the saturation state can enhance bLf's anti-cancer activities.

Methods: Apo-bLf ( $\mathrm{Fe}^{3+}$ free) and Fe-bLf ( $>90 \% \mathrm{Fe}^{3+}$ Saturated) were therefore, tested in MDA-MB-231 and MCF-7 human breast cancer cells in terms of cytotoxicity, proliferation, migration and invasion. Annexin-V Fluos staining was also employed in addition to apoptotic protein arrays and Western blotting to determine the specific mechanism of bLf-induced apoptosis with a key focus on p53 and inhibitor of apoptosis proteins (IAP), specifically survivin.

Results: Apo-bLf induced significantly greater cytotoxicity and reduction in cell proliferation in both cancer cells showing a time and dose dependent effect. Importantly, no cytotoxicity was detected in normal MCF-10-2A cells. Both forms of bLf significantly reduced cell invasion in cancer cells. Key apoptotic molecules including p53, Bcl-2 family proteins, IAP members and their inhibitors were significantly modulated by both forms of bLf, though differentially in each cell line. Most interestingly, both Apo-bLf and Fe-bLf completely inhibited the expression of survivin protein (key IAP), after $48 \mathrm{~h}$ at 30 and $40 \mathrm{nM}$ in cancer cells.
\end{abstract}

Conclusions: The capacity of these forms of bLf to target survivin expression and modulation of apoptosis demonstrates an exciting potential for bLf as an anti-cancer therapeutic in the existing void of survivin inhibitors, with a lack of successful inhibitors in the clinical management of cancer.

Keywords: Bovine lactoferrin (bLf), Apoptosis, Breast cancer, Survivin, p53, Invasion

\section{Background}

Apoptosis is a key target for anti-cancer therapy given that it is commonly disrupted in tumourigenesis, allowing diseased cancerous cells to remain and proliferate within the body. Inhibitor of apoptosis proteins (IAPs), play a key role in the ability of cancer to avoid apoptotic signals. Survivin is a $16 \mathrm{kDa}$ protein of the IAP family that enhances cell survival and is over expressed in many cancer cells [1]. Due to its overexpression in cancer, survivin is a key target for cancer therapy. Survivin inhibits apoptosis by directly binding to pro-apoptotic molecules, including caspase family proteins, allowing the progression

\footnotetext{
*Correspondence: rupinder.kanwar@deakin.edu.au

Nanomedicine - Laboratory for Immunology and Molecular Biomedical Research, Molecular and Medical Research Facility, School of Medicine, Faculty of Health, Deakin University, Geelong, Victoria, Australia
}

of cell growth and survival [1-3]. The caspase family consists of initiator caspases- 8 and -9 of the extrinsic and intrinsic pathways respectively, as well as executioner caspases- 3 and -7 .

Lactoferrin (Lf) is a naturally occurring, ferric $\left(\mathrm{Fe}^{3+}\right)$ iron binding glycoprotein [4]. Naturally, Lf has antibacterial and antimicrobial properties and is present in external mammalian excretions including tears, sweat and most importantly milk [4-6]. Bovine lactoferrin (bLf) has been associated with immune boosting and anti-carcinogenic properties [7]. Purified bLf has been shown to increase interferon- $\gamma$ (IFN- $\gamma$ ), caspase-1 and interleukin-18 (IL-18) $[5,8]$ as well as increasing the levels of immune cells in various mice models $[5,8,9]$. BLf is approved by the Therapeutic Goods Administration (Australia), Food and Drug Administration (USA) and the European Food Safety 
Authority for use in food, sports medicine and nutritional products [10-12].

Native bLf (15-20\% iron saturated) has been shown to inhibit growth of colon, lung, bladder, squamous and mammary gland tumour cells [13-19] and had been reported to induce apoptosis in colon, lung, stomach and breast cancers $[6,20]$. Specifically, apoptosis was reported in two breast cancer cells lines T47D and HS578D with native bLf at concentrations of 0.125-125 $\mu \mathrm{M}$ along with a reduction in cell migration [21]. Activation of apoptosis by bLf has been reported via the modulation of both the extrinsic and intrinsic pathways. BLf has been reported to up-regulate the sensitivity of extrinsic pathway death receptor Fas as well as inducing caspase- 3 and -8 cleavage in colon cancer models [22, 23] Results from the same studies also indicated up-regulation of pro-apoptotic Bcl-2 family genes Bax and Bid. Studies have also reported that native bLf significantly decreased the levels of intrinsic anti-apoptotic protein Bcl-2 in stomach cancer cells [20].

Whilst native bLf is approximately $15-20 \%$ saturated, it can be modified to forms with different levels of iron: Apo-bLf ( $<5 \%$ iron saturation) and Holo-bLf (100\% iron saturated) $[4,24]$. In comparison to Apo-bLf, iron saturated bLf is more resistant to in vivo gut digestion [25, 26]. The concept that bLf iron saturation levels can affect its anti-tumour activity was not tested until 2008, when we reported that iron saturated (>98\%) Fe-bLf, when fed orally to mice, displays anti-tumour properties, increasing apoptosis and cytotoxicity as well as targeting angiogenesis [24]. Importantly, Fe-bLf has been shown to restore red and white bloods cells following chemotherapy [24] and increase the sensitivity of tumours to chemotherapeutic drugs [25, 27]. Fe-bLf encapsulated in ceramic nanocarriers has also proved very effective. When fed orally, we observed a complete inhibition of tumourigenesis in colon cancer xenograft mice in both prevention and treatment models with tumour rejection and regression respectively [25]. In addition, iron-free (Apo-bLf) and selenium saturated bLf (Se-bLf) have shown anti-oxidant effects in colon cancer cells [28, 29].

BLf has a proven high safety profile reported widely by pre-clinical animal studies and human clinical trials $[6$, $25,30,31$. Apo-bLf is thought to have enhanced anticancer properties through its capacity to bind free $\mathrm{Fe}^{3+}$, acting as an iron chelating agent [32-36]. This could be of particular importance in breast cancer in relation to iron metabolism [37]. Abnormalities in iron metabolism have been associated with chemoresistance in breast cancer cells [38]. As iron is essential for many cellular processes and with a rapid growth rate, high iron levels are essential in the tumour microenvironment [39, 40] allowing for cell growth, proliferation and angiogenesis. Thus chelating agents that can inhibit these processes have great potential.
While apoptosis has been observed in many cancer cell types with native bLf, the specific mechanism of apoptosis in breast cancer cells following Apo-bLf and Fe-bLf treatment remains unclear; we hypothesised that apoptosis would also be initiated in two breast cancer cells MDA-MB-231 and MCF-7 with Apo-bLf and FebLf. It was hypothesised that these two bLf forms would differentially (due to differences in iron level) modulate the apoptosis, and molecules from each of the IAP and caspase families. The effects of both Apo-bLf and Fe-bLf in MDA-MB-231 and MCF-7 human breast adenocarcinoma cell lines were therefore investigated. Both forms of bLf were also tested on non-tumourigenic mammary epithelial cell line, MCF-10-2A. Furthermore, tumourigenic properties such as migration and invasion were also studied in breast cancer cells. Full investigation into the mechanisms and pathways activated in terms of apoptosis following Apo-bLf and Fe-bLf treatment was performed.

\section{Methods}

\section{Cell culture/Maintenance}

MDA-MB-231, MCF-7 and MCF-10-2A cell lines were obtained from the American Type Culture Collection (ATCC). MDA-MB-231 were maintained in Leibovitz's L15 medium (Life Technologies) supplemented with 10\% FBS and antibiotic-antimytotic. MCF-7 cells were maintained in Eagle's Minimum Essential Medium (EMEM, Life Technologies) supplemented with 10\% FBS, antibioticantimytotic and $0.01 \mathrm{mg} / \mathrm{ml}$ bovine insulin (Life Technologies). MCF-10-2A cells were maintained in Dulbeccos modified Eagle medium (DMEM)/Ham's F12 medium (Life Technologies) with $10 \%$ horse serum, $0.01 \mathrm{mg} / \mathrm{ml}$ bovine insulin, $20 \mathrm{ng} / \mathrm{ml}$ epidermal growth factor, $100 \mathrm{ng} / \mathrm{ml}$ Cholera toxin, $500 \mathrm{ng} / \mathrm{ml}$ hydrocortisone and antibioticantimytotic. Cells were incubated at $37{ }^{\circ} \mathrm{C}, \mathrm{MCF}-7$ and MCF-10-2A cells in the presence of $5 \% \mathrm{CO}_{2}$.

\section{Lactoferrin preparation}

Apo-bLf (iron free) was prepared from commercial grade pure, endotoxin (LPS) free, native bLf. Briefly, $80 \mathrm{mg} / \mathrm{ml}$ native bLf was dissolved in Milli-Q water and iron released by reducing $\mathrm{pH}$ to 2.06 . The bLf solution was then dialysed in $50 \mathrm{kDa}$ molecular weight cut-off dialysis tubing against $0.1 \mathrm{M}$ citric acid for $48 \mathrm{~h}$ and $\mathrm{pH}$ adjusted back to 8.0. Fe-bLf (iron-saturated) was prepared by the addition of ferric nitriloacetate (Fe-NTA) to Apo-bLf drop wise until the solution reached a deep red colour indication iron saturation. The Fe-bLf solution was then dialysed against Milli-Q water for $48 \mathrm{~h}$. Protein estimation was performed using the Coomassie Plus (Bradford) Protein Assay (Thermo Scientific) and purification was confirmed via SDS-PAGE (results not shown). 


\section{Lactate dehydrogenase release (LDH) release assay}

Cell cytotoxicity was determined using a cytotoxicity detection, lactate dehydrogenase release (LDH) assay kit (Roche). Cells were grown in 96-well plates $\left(2 \times 10^{5}\right.$ cells $/ \mathrm{ml}, 200 \mu \mathrm{l} /$ well) for $48 \mathrm{~h}$ prior to 24 and $48 \mathrm{~h}$ treatment with 5, 10, 20, 30 and 40 nM Apo-bLf and Fe-bLf. Supernatants from cells were incubated with LDH reaction mixture and incubated for $30 \mathrm{~min}$ in fresh microplates. Plates were then read at a wavelength of $492 \mathrm{~nm}$ with a reference of $620 \mathrm{~nm}$. High (100\% cytotoxicity) and low ( $0 \%$ cytotoxicity) controls were used to calculate relative percentages of each treatment group.

\section{CyQUANT ${ }^{\oplus}$ assay}

The CyQUANT $^{\circ}$ cell proliferation assay (Life Technologies) was performed on both MDA-MB-231 and MCF-7 treated cells as per manufacturer's instructions. Briefly, cells were plated in 96-well plates, treated with both ApobLf and Fe-bLf for 24 and $48 \mathrm{~h}$ at concentrations of 20, 30 and $40 \mathrm{nM}$. Treatment media was then removed and mircoplates were frozen at $-80{ }^{\circ} \mathrm{C}$ overnight. Plates were then thawed and cells were incubated with CyQUANT ${ }^{\circ}$ GR dye/cell lysis buffer prepared as per kit instructions. Plates were then read at $480 \mathrm{~nm}$ excitation and $520 \mathrm{~nm}$ emission maxima using a fluorescent spectrophotometer.

\section{Immunofluorescence}

Immunofluorescence was performed on both cancer cells for bLf to determine the localisation of bLf into the cells. Cells were seeded onto 8-chamber well slides and let to grow until 70\% confluent. Cells were then treated with either form of bLf at $40 \mathrm{nM}$ for $4 \mathrm{~h}$. Cells were then fixed in $4 \%$ paraformaldehyde and blocked in 2\% BSA followed by incubation in anti-bovine lactoferrin primary antibody (Bethyl Laboratories) and Alexa-Fluor 594 conjugated anti-goat secondary antibody (Life Technologies) for $1 \mathrm{~h}$ each. Cells were then washed in phosphate buffered saline (PBS) before chamber removal and mounting media containing DAPI application. Slides were then covered, sealed and imaged via confocal microscope and software (Leica TCS SP5).

\section{Migration/Invasion assay}

Both migration and invasion assays were performed in 24 well plates with $8 \mu \mathrm{m}$ pore membrane, ThinCert ${ }^{\mathrm{tm}}$ cell culture inserts (Greiner). Briefly, plates were set up with media containing $10 \%$ FBS in the lower compartment. Inserts were then placed into wells and $200 \mu \mathrm{l}$ of $1 \%$ FBS media containing $2 \times 10^{4}$ cells was seeded into each insert. To this, treatments of 5 or $10 \mathrm{nM} \mathrm{Apo-bLf}$ or FebLf were added and total system was incubated for $24 \mathrm{~h}$. After which, ThinCert ${ }^{\mathrm{TM}}$ chambers were removed and membranes fixed in $4 \%$ paraformaldehyde. Cells were stinaed with $0.2 \%$ crystal violet and cells on the bottom (i.e. those that had migrated through the membrane) were counted (5 representative fields) and averaged. Invasion assays were performed in the same way however an artificial extracellular matrix (ECM) was placed on the membrane prior to cell seeding to test invasive properties. MaxGel ${ }^{\text {tw }}$ ECM (Sigma-Aldrich) was used according to manufacturer's instructions. Both invasion and migration were represented as a percentage of control (untreated) cell counts.

\section{Annexin-V-fluos apoptosis assay}

Apoptosis was detected via an Annexin-V-Fluos staining kit (Roche) according to manufacturer's protocol. MDAMB-231 and MCF-7 cells grown in 12 well plates were treated with either Apo-bLf or Fe-bLf at 20 or $40 \mathrm{nM}$ for $24 \mathrm{~h}$. Following treatment, cells were trypsinised and pelleted, washed in PBS and again pelleted. Cells were resuspended in Annexin-V-Fluos labelling solution consisting of Annexin-V-Fluorescein labelling reagent and propidium iodide (PI). Cells were incubated in the labelling solution for $20 \mathrm{~min}$ at room temperature before analysis via flow cytometry (BD Biosciences). Cells were gated according to PI and Annexin-V staining. Cells positive for Annexin- $\mathrm{V}$ only were considered early apoptotic, cells positive for PI only were considered necrotic and cells double positive were taken as late apoptotic/ dead. Assays were performed in duplicate.

\section{Apoptotic array}

Human apoptosis protein arrays (R\&D Systems) were employed to screen 35 pro and anti-apoptotic molecules from both the extrinsic and intrinsic pathways. Capture and control antibodies were spotted in duplicate onto nitrocellulose membranes which were subsequently incubated with $250 \mu \mathrm{g}$ whole cell lysate overnight. Following incubation with kit buffers and reagents, membranes were viewed using chemiluminescence detection and spot densities analysed via Image J (National Institutes of Health).

\section{Western blotting}

Western Blotting was performed with cell lysates prepared from cells treated for $48 \mathrm{~h}$ in either Apo or Fe-bLf at concentrations of 20,30 and $40 \mathrm{nM}$ as well as from untreated cells. After treatments, cells were washed in sterile PBS and lysed in RIPA buffer $(0.6057 \mathrm{~g}$ Tris base, $0.877 \mathrm{~g} \mathrm{NaCl}, 10 \mathrm{ml}$ Nonident P-40, $5 \mathrm{ml}$ 10\% Na-deoxycholate, $1 \mathrm{ml} 10 \%$ sodium dodecyl sulphate, $\mathrm{pH}$ set to 7.5 , adjusted to $100 \mathrm{ml}$ with $\mathrm{H}_{2} \mathrm{O}$ ) for $30 \mathrm{~min}$ before centrifugation and supernatant collection. $100 \mu \mathrm{g}$ of total protein (determined via Bradford assay) was then used for sodium dodecyl sulphate polyacrylamide gel electrophoresis (SDS-PAGE). Following electrophoresis, proteins were transferred to PVDF membranes which were 
subsequently blocked in $1 \%$ skim milk powder made up in Tris buffered saline (TBS, $2.42 \mathrm{~g}$ Tris base, $8 \mathrm{~g} \mathrm{NaCl}$, made up to $1 \mathrm{~L}$ with autoclaved Milli-Q water, $\mathrm{pH}$ 7.6) for $1 \mathrm{~h}$. Membranes were then incubated overnight in appropriate primary antibodies (Survivin and Tubulin: Santa Cruz, all other antibodies: Cell Signalling) diluted to 1:1000 in TBS followed by $1 \mathrm{~h}$ in appropriate secondary antibodies (Sigma-Aldrich) with washes after each incubation. Membranes were exposed to chemiluminescent reagents and imaged via ChemiDoc XRS camera (BioRad). Band densities analysed via Image J (National Institutes of Health).

\section{Statistical analysis}

All statistical analysis was performed via Student's t-test.

\section{Results}

BLf induces cytotoxicity and reduces the proliferative ability of MDA-MB-231 and MCF-7 cells

The effect of both Apo-bLf and Fe-bLf on cytotoxicity and proliferation were evaluated in the breast cancer cells MDA-MB-231 and MCF-7. Cells were treated with bLf for 24 and $48 \mathrm{~h}$ at concentrations of $0,5,10,20,30$ and $40 \mathrm{nM}$. In order to quantify cell death, Lactate dehydrogenase (LDH) cytotoxicity assays were employed to determine cytotoxicity.

Apo-bLf was the most effective at inducing cell cytotoxicity with significant increases in cytotoxicity at concentrations of 20, 30 and $40 \mathrm{nM}$ in MDA-MB-231 (133.05\%, $p=0.003,112.53 \%, p=0.003$ and $110.17 \%, p=$ 0.007 , respectively) and MCF-7 cells $(68.58 \%, p=0.001$, $90.68 \%, p=0.00001$ and $99.31 \%, p=0.000006$, respectively) after 48 h (Fig. 1a). Furthermore, Apo-bLf demonstrated significant toxicity after $24 \mathrm{~h}$ in MCF-7 cells at concentrations of $20 \mathrm{nM}(25.93 \%, p=0.02), 30 \mathrm{nM}$ $(40.09 \%, p=0.001)$ and $40 \mathrm{nM}(61.97 \%, p=0.001)$ (Fig. 1b). Fe-bLf demonstrated significant increases in cytotoxicity in MDA-MB-231 cells at concentrations of 10,20 and $30 \mathrm{nM}(51.81 \%, p=0.04,61.76 \%, p=0.01$ and $42.01 \%, p=0.048$ ) after $48 \mathrm{~h}$ (Fig. 1a) yet no significant cytotoxicity in MCF-7 cells (Fig. 1b).

$\mathrm{CyQUANT}^{\circ}$ assay results indicated a reduction in proliferation following treatments with both Apo-bLf and Fe-bLf after $48 \mathrm{~h}$ in MDA-MB-231 cells (Fig. 1c). ApobLf significantly reduced proliferation at concentrations of 30 and $40 \mathrm{nM}(67.30 \%, p=0.01$ and $54.87 \%, p=0.003$, respectively) and Fe-bLf at concentrations of 20, 30 and $40 \mathrm{nM}(74.86 \%, p=0.04,52.89 \%, p=0.003$ and $46.40 \%$, $p=0.008)$ after $48 \mathrm{~h}$. Furthermore, Apo and Fe-bLf reduced proliferation after $48 \mathrm{~h}$ in MCF-7 cells at $40 \mathrm{nM}$ (53.93\%, $p=0.03$ and $51.35 \%, p=0.01$ respectively) (Fig. 1d). No significant increase in proliferation was observed in any treatment condition in either cell line.
Morphological images (Fig. 2a and b) indicated significant cell death after $48 \mathrm{~h}$. Cells in treatment groups showed detachment from culture surfaces, blebbing and rounded edges. Cell fragmentation and decrease in number was also observed compared with untreated cells over the same time period. These effects were observed more frequently with increasing concentration in MDAMB-231 (Fig. 2a) and MCF-7 (Fig. 2b). These results indicate a time and dose dependant effect of Apo-bLf on MDA-MB-231 and MCF-7 cells in terms of increasing cell cytotoxicity and decreasing cell proliferation. Furthermore, these results also highlight that Fe-bLf is less effective when compared with Apo-bLf in these breast cancer cells.

\section{Apo-bLf and Fe-bLf show no cytotoxic effects in MCF-10-2A mammary epithelial cells}

Both Apo-bLf and Fe-bLf were also tested in a normal, non-tumourigenic mammary epithelial cell line MCF10-2A. LDH cytotoxicity assays were performed on cells treated for 24 and $48 \mathrm{~h}$ at concentrations of $5,10,20,30$ and $40 \mathrm{nM}$. No significant increase in cytotoxicity was observed after either 24 or $48 \mathrm{~h}$ with any of the Apo-bLf and Fe-bLf treatments (Fig. 1e).

\section{Apo-bLf and Fe-bLf efficiently internalizes into treated cells}

BLf is known to internalize into normal and cancer cells through cell surface (membrane) receptor mediated endocytosis $[10,30,41,42]$. In order to determine the level of internalisation and localisation of bLf within breast cancer cells, we performed immunofluorescence. Cells were treated with either Apo-bLf or Fe-bLf at $40 \mathrm{nM}$ for $4 \mathrm{~h}$. A reduced time period was used to reduce cell death so that cells could still be visualised by confocal microscopy. Both forms of bLf internalised into MDAMB-231 (Fig. 2c) cells with fragmentation displayed in cells treated with Fe-bLf at $40 \mathrm{nM}$. Both forms of bLf were localised in the membrane, cytoplasm and nucleus of the cells. Untreated MCF-7 cells displayed healthy, cluster formation (Fig. 2d). After treatment with both Apo-bLf and Fe-bLf, internalisation of bLf into the membrane, cytoplasm and nucleus was observed (Fig. 2d). It is apparent that Apo-bLf induces mass cell fragmentation (Fig. 2d) which is due to the high cytotoxic potential of Apo-bLf. Cell clusters were also much smaller in treated cells compared with untreated cells, indicating the effect of treatment on cell viability following bLf internalisation.

\section{Apo-bLf and Fe-bLf treatments decrease the migration and invasion potential of breast cancer cells}

As migration and invasion are key properties of cancer cells leading to metastases and secondary tumour sites within the body, assays were performed to determine the 


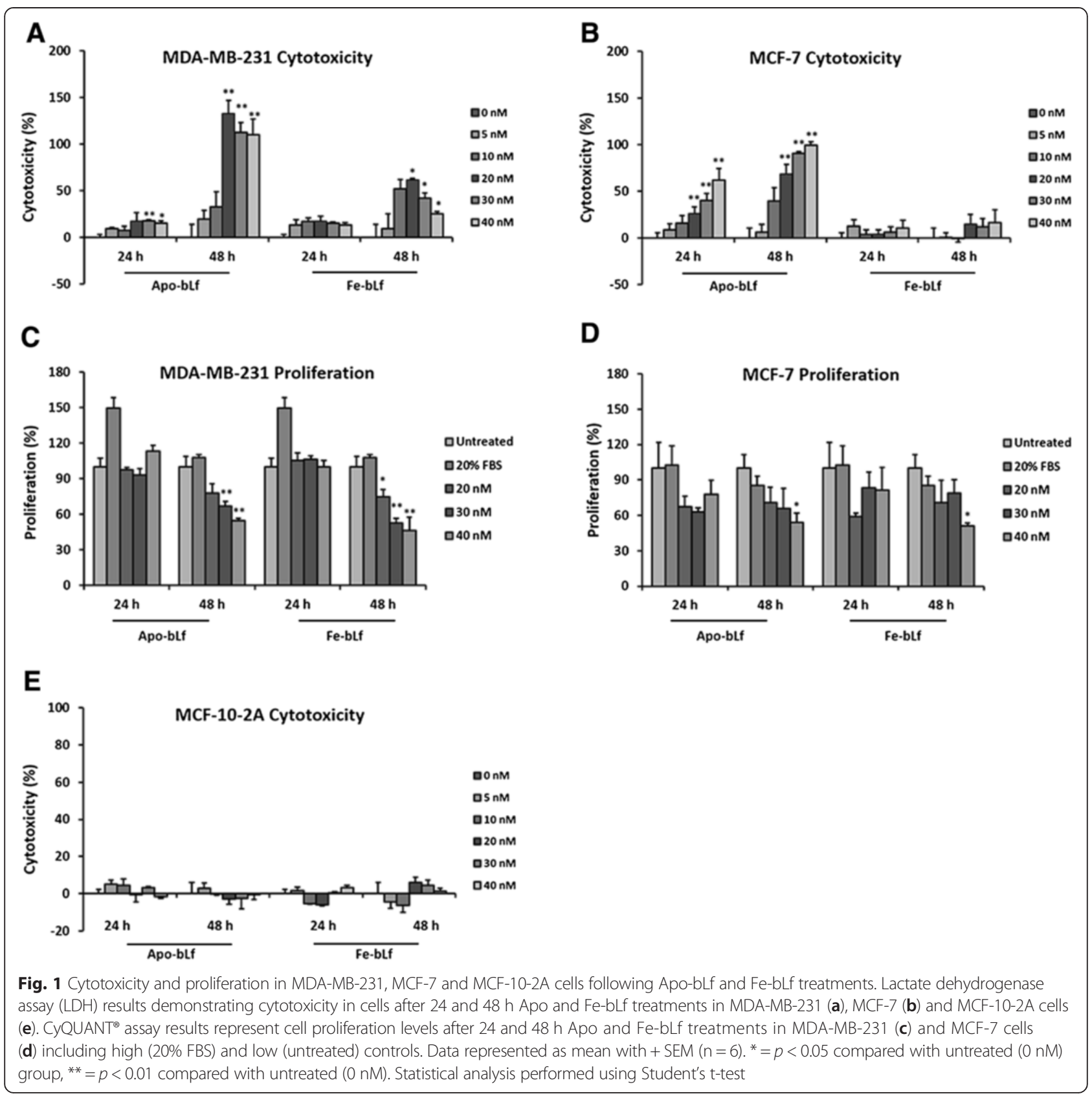

effects of bLf in regards to these properties. Migration assays indicated a significant reduction in the capacity of MDA-MB-231 and MCF-7 (Fig. 3a) cells to migrate through a porous membrane after treatment for $24 \mathrm{~h}$ with each Apo-bLf and Fe-bLf at concentrations of 5 and $10 \mathrm{nM}$. The greatest reduction in migration was observed with $10 \mathrm{nM}$ Apo-bLf with $26.45 \%(p=0.001)$ of MDA-MB-231 and 38.78\% ( $p=0.001)$ of MCF-7 cells migrating. Invasion assays (Fig. $3 \mathrm{~b}$ and $\mathrm{c}$ ) were performed with ECM. The same trend was observed in MDA-MB-231 cells with $29.85 \%(p=0.001)$ of cells invading after treatment with $10 \mathrm{nM}$ Apo-bLf. MCF-7 showed a large reduction with $10 \mathrm{nM}$ Apo-bLf (50.00\%, $p=0.003$ ) however the greatest reduction in invasion was with $10 \mathrm{nM}$ Fe-bLf treatments with $26.25 \%$ ( $p=$ $0.00008)$ invasion.

Both bLf forms induce significant apoptosis at a different rates in MDA-MB-231 and MCF-7 cells

In order to determine if cell death was caused by apoptosis, Annexin-V-Fluos labelling was performed on each MDA-MB-231 and MCF-7 cells (Fig. 4). Cell were treated with Apo-bLf or Fe-bLf at 20 and $40 \mathrm{nM}$ for $24 \mathrm{~h}$. Labelling was detected via Flow cytometry and gating was 


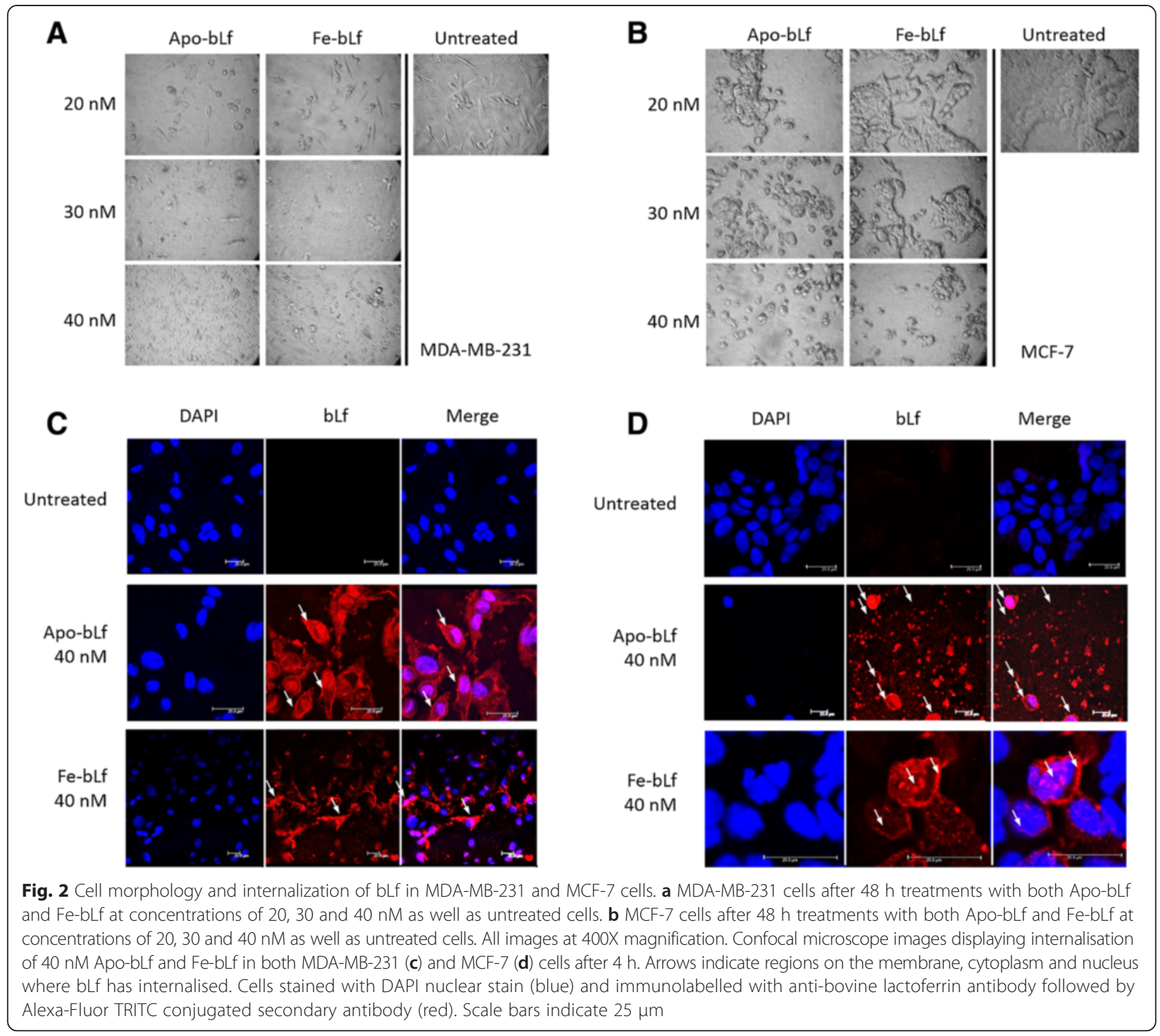

performed on both dual (Fig. 4c) and single channel plots (Annexin-V and Propidium Iodide). Results indicated increases in apoptotic cell death in MDA-MB-231 cells treated with bLf with significant increased total apoptosis in cells treated with Apo-bLf at $40 \mathrm{nM}(23.30 \%, \mathrm{p}=0.03)$ (Fig. 4a). Results from MCF-7 cells showed increased apoptosis in all treatment groups with significant apoptosis observed in cells treated with $40 \mathrm{nM}$ Apo-bLf $(46.85 \%, p=0.05)$ and Fe-bLf at $20 \mathrm{nM}(53.60 \% p=0.02)$ and $40 \mathrm{nM}(65.15 \%, p=0.04)$ (Fig. 4b). Furthermore, decreased viable cells were observed in MDA-MB-231 cells after Apo-bLf at $40 \mathrm{nM}$ and in both Fe-bLf treatment groups and in all MCF-7 treatment groups however no significant increase in necrotic cells was observed in any of the treatment groups (Table 1). This indicated that both Apo-bLf and Fe-bLf were inducing apoptosis in each cell line.
To determine the mechanism of action of apoptosis induced by bLf, apoptotic protein arrays were performed on each MDA-MB-231 (Fig. 5) and MCF-7 (Fig. 6) cells following treatments with Apo-bLf and Fe-bLf for $24 \mathrm{~h}$. Results indicated different mechanisms of action between the two forms of bLf and between the cells. MDA-MB-231 showed significant reduction in survivin expression along with increased expression of HTRA2 with each Apo-bLf and Fe-bLf (Fig. 5b). In addition, ApobLf reduced cIAP2 and SMAC was increased with Fe-bLf (Fig. 5b). In MCF-7 cells, HTRA2 and SMAC were both significantly increased with both forms of bLf, with a stronger effect observed with Apo-bLf (Fig. 6b). These results indicate that bLf is having an impact on the IAP mechanism, allowing apoptosis to progress by activating SMAC and HTRA2 which subsequently bind IAP proteins, preventing their inhibition of the caspase cascade. 


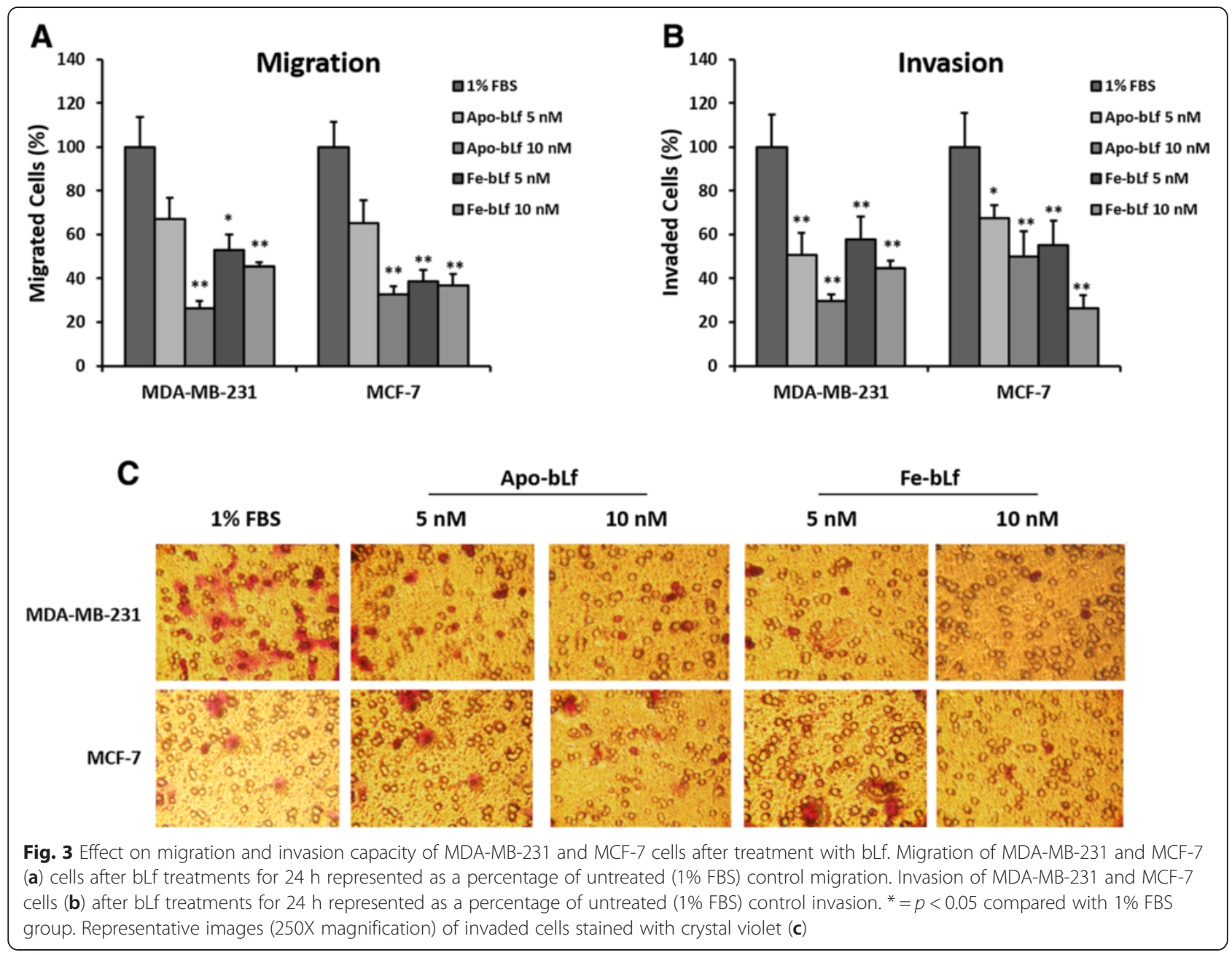

Furthermore, results indicate apoptosis in MDA-MB231 cells occurring via the intrinsic pathway with a significant reduction in expression of anti-apoptotic proteins in Bcl-2 (Apo-bLf) and PON2 (both forms of bLf) (Fig. 5a). A reduction in extrinsic proteins FADD and Fas (Fig. 5c) was also observed however the opposite occurring in MCF-7 (Fig. 6c) with extrinsic proteins FADD and TNF R1 each upregulated with both forms of bLf. Furthermore, MCF-7 cell also show significant increases of pro-apoptotic proteins Bad and cytochrome C (Fig. 6a \& d).

Cell stress proteins in MDA-MB-231 cells, HMOX1 and HSP60 were both reduced with Apo-bLf (Fig. 5e) as were cell cycle regulators claspin, p21, p27, phospho-p53 (S15, S46 and S392) and phospho-Rad17 (S635) (Fig. 5 f). Claspin was also significantly reduced with both Apo-bLf and Fe-bLf (Fig. 5f). In MCF-7 cells, cell stress proteins were increased by both Apo-bLf and Fe-bLf including HIF1 $\alpha$, HMOX2, HSP27, HSP60 and HSP70 (Fig. 6e). Finally, cell cycle regulator p21 was increased in MCF-7 cells with Apo-bLf, Claspin with Fe-bLf and phospho-p53
S15 and S46 were increased with both Apo-bLf and FebLf (Fig. $6 \mathrm{f}$ ).

\section{Apo-bLf and Fe-bLf forms induce increase in caspase cleavage}

Following the observations form the Apoptotic array that bLf modulated aspects of both the intrinsic and extrinsic pathways, as well as increases in cleaved caspase-3, the effect of bLf on cleaved initiator caspase-8 (extrinsic) and caspase-9 (intrinsic) were assed via Western blotting. In addition, pro and cleaved effector caspase- 3 were also analysed. MDA-MB-231 and MCF-7 cells were both treated with $40 \mathrm{nM}$ Apo-bLf and Fe-bLf for $24 \mathrm{~h}$. Following treatments, cells were lysed with RIPA buffer and lysates were separated via SDS-PAGE followed by Western blotting. Identical gels were run and Western blotting performed for GAPDH. Fold change was calculated by determining band densities via ImageJ software, normalizing proteins with GAPDH and calculating fold change relative to untreated cells. 


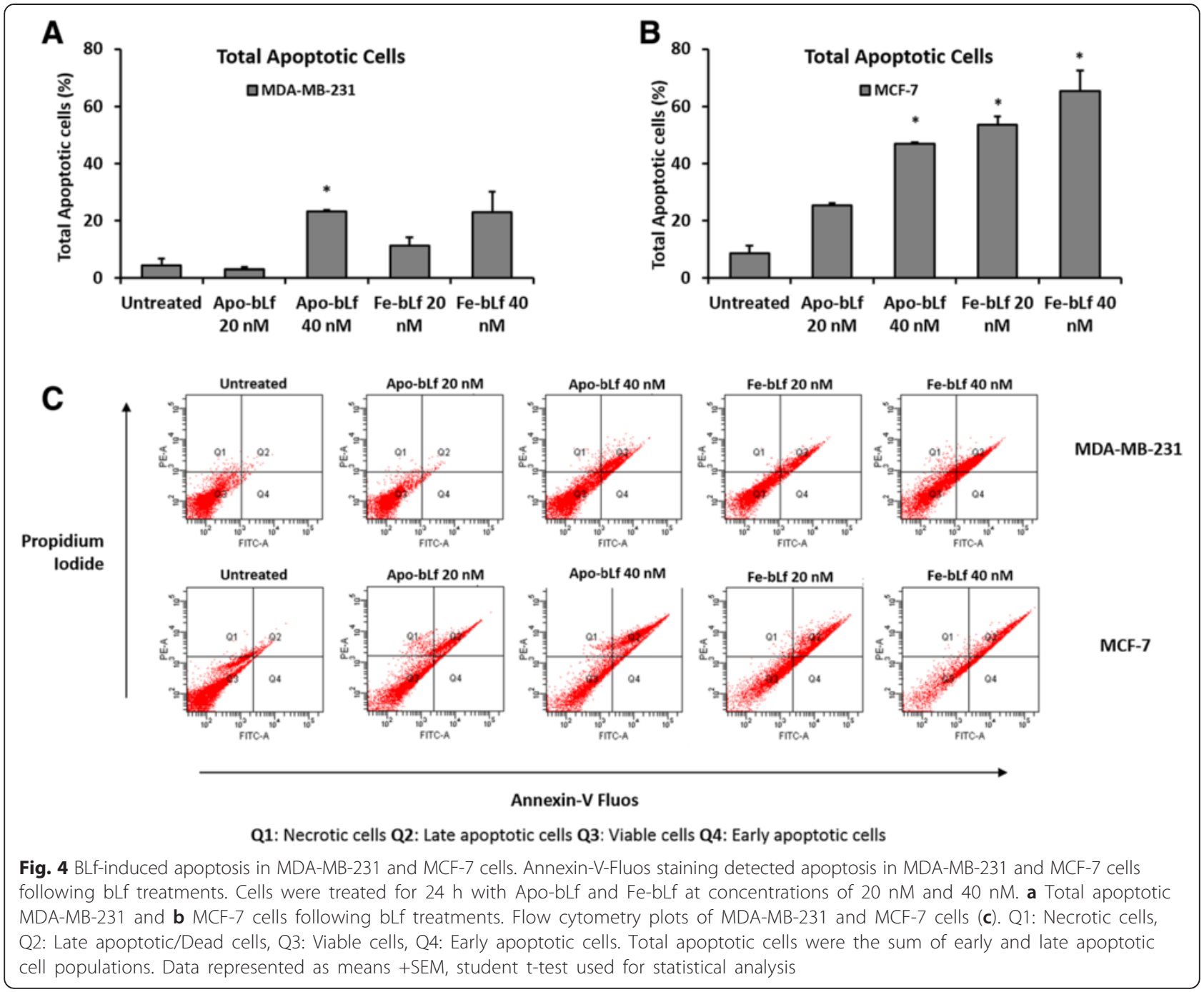

Table 1 Annexin- $V$ results following bLf treatments in breast cancer cells

\begin{tabular}{llllll}
\hline & & Early Apoptotic Cells & Late Apoptotic Cells & Viable Cells & Necrotic Cells \\
\hline MDA-MB-231 & Untreated & $1.75 \pm 1.15$ & $2.50 \pm 2.10$ & $94.85 \pm 3.25$ & $0.85 \pm 0.05$ \\
& Apo-bLf 20 nM & $1.90 \pm 0.60$ & $1.10 \pm 0.40$ & $96.2 \pm 1.40$ & $0.85 \pm 0.35$ \\
& Apo-bLf 40 nM & $5.55 \pm 0.65$ & $17.75 \pm 0.05^{*}$ & $75.4 \pm 0.10^{*}$ & $1.10 \pm 0.5$ \\
& Fe-bLf 20 nM & $1.90 \pm 0.30$ & $9.30 \pm 3.30$ & $87.7 \pm 3.40$ & $1.10 \pm 0.20$ \\
& Fe-bLf 40 nM & $3.75 \pm 1.95$ & $19.35 \pm 6.85$ & $74.00 \pm 8.80$ & $2.90 \pm 0.00$ \\
MCF-7 & Untreated & $3.40 \pm 3.20$ & $5.25 \pm 3.25$ & $88.60 \pm 7.30$ & $2.70 \pm 0.90$ \\
& Apo-bLf 20 nM & $2.50 \pm 0.40$ & $22.85 \pm 9.65$ & $64.95 \pm 3.85$ & $9.75 \pm 6.15$ \\
& Apo-bLf 40 nM & $6.15 \pm 0.55$ & $40.7 \pm 7.30^{*}$ & $51.00 \pm 6.70^{*}$ & $2.20 \pm 0.00$ \\
& Fe-bLf 20 nM & $12.30 \pm 0.30$ & $41.3 \pm 1.40^{*}$ & $45.45 \pm 1.65^{*}$ & $0.95 \pm 0.05$ \\
& Fe-bLf 40 nM & $21.65 \pm 1.65^{*}$ & $43.5 \pm 12.10$ & $34.15 \pm 10.05^{*}$ & $0.70 \pm 0.40$ \\
\hline
\end{tabular}

Annexin-V-Fluos staining results determined via Flow cytometry. Total populations acquired were plotted in terms of both single and dual fluorophores. Dual channel plots were divided in to quadrants: Q1: Necrotic cells, Q2: Late apoptotic/Dead cells, Q3: Viable cells, Q4: Early apoptotic cells. Single channel plots were used to determine total numbers of cells labelled with Annexin- $V$ or propidium iodide. Table 1 shows average values for individual gating of both dual and single channel plots + SEM. Statistical analysis was performed via Student's t-test 
A

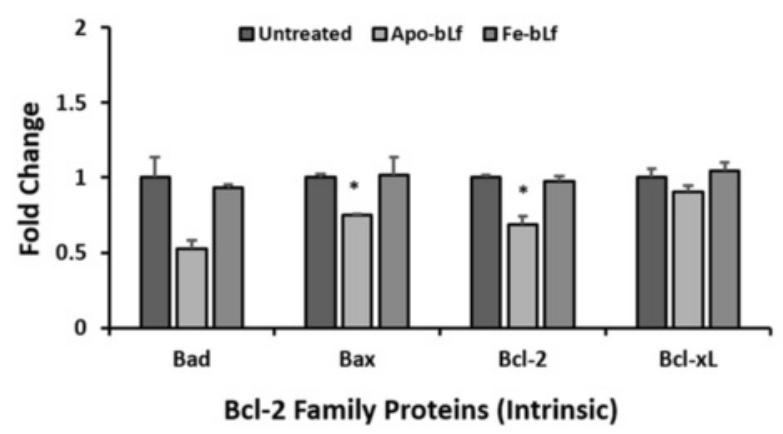

C

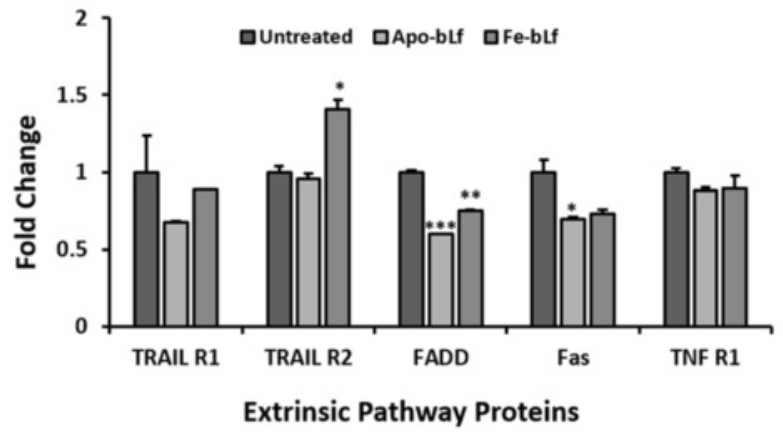

E

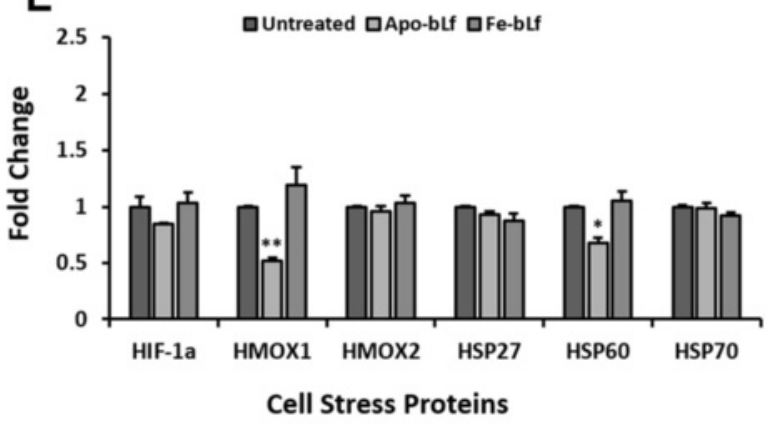

B

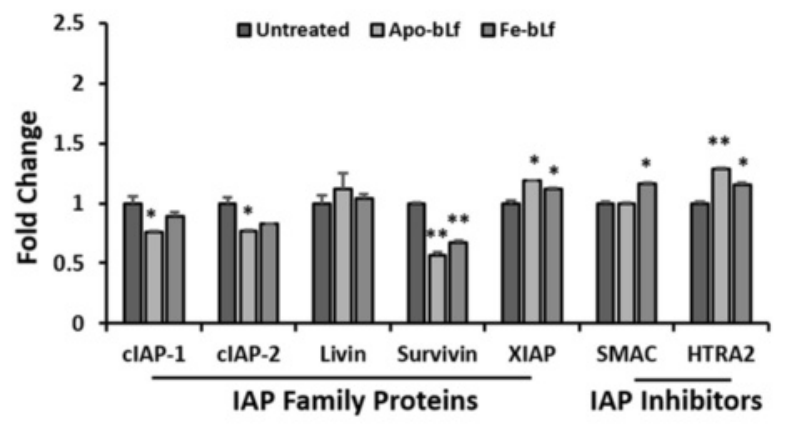

D

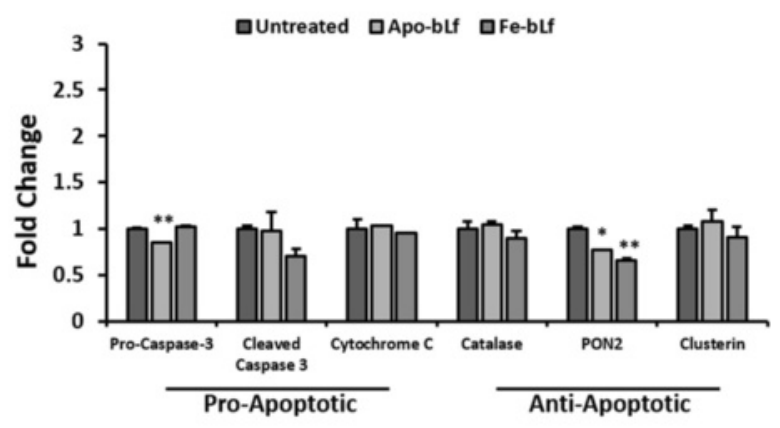

$\mathbf{F}$

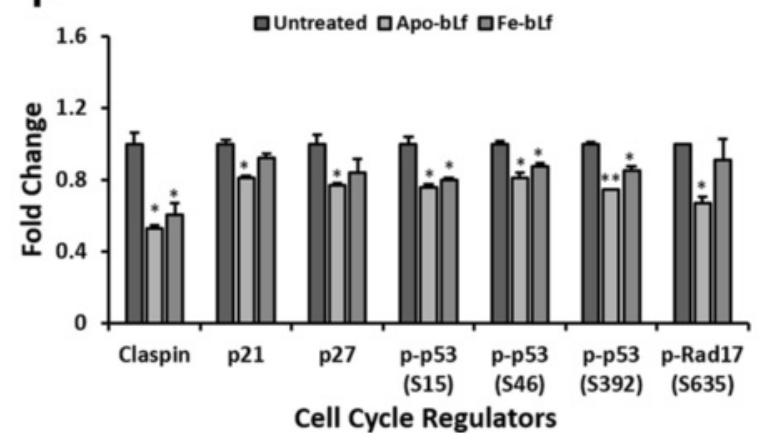

Fig. 5 Apoptosis protein array MDA-MB-231 breast cancer cells. Apoptosis protein array results following incubation of MDA-MB-231 cell lysate after treatments with Apo-bLf and Fe-bLf at $40 \mathrm{nM}$ for $24 \mathrm{~h}$. Cell lysate $(250 \mathrm{\mu g})$ incubated with nitrocellulose membrane pre-labelled with capture antibodies (duplicate spots) and detected via chemiluminescence. a Bcl-2 family proteins Bad, Bax, Bcl-2 and BCl-xL. b Inhibitor of apoptosis (IAP) proteins CIAP-1 and 2, Livin, Survivin and XIAP, and inhibitors SMAC and HTRA2. c Extrinsic pathway proteins and receptors TRAIL 1 and 2, FADD, Fas and TNF R1. d Pro-apoptotic proteins Pro-caspase-3, Cleaved Caspase-3 and Cytochrome C, anti-apoptotic proteins Catalase, PON2 and Clusterin. e Cell stress proteins HIF-1a, HMOX1, HMOX2, HSP27, HSP60 and HSP70. f Claspin, p21, p27, phospho-p53 (S15), phospho-p53 (S46), phospho-p53 (S392) and phospho-Rap17 (S635). Average density determined using ImageJ software and fold change calculated compared with untreated. Data represented as means with + SEM. ${ }^{*}=p<0.05,{ }^{* *}=p<0.01,{ }^{* * *}=p<0.001$ compared with the untreated group. Statistical analysis was performed via Student's t-test

Cleaved caspases-8 and -9 were increased with $40 \mathrm{nM}$ Apo-bLf in MDA-MB-231 cells (Fig. 7a). Fe-bLf however did not show increases in either cleaved caspase-8 or -9 . Apo-bLf increased the active fragment $(18 \mathrm{kDa})$ of cleaved caspase- 8 by 2.3 fold compared with untreated cells. Most notably however, cleaved caspase- 9 was increased by 8.9 fold with Apo-bLf.
In MCF-7 cells, both cleaved caspases-8 and -9 were increased with $40 \mathrm{nM}$ Apo-bLf and Fe-bLf (Fig. 7b). The effects of Apo-bLf and Fe-bLf were similar in their effects on cleaved caspases- 8 and -9 . Active caspase- 8 (18 kDa fragment) was increased to 1.5 and 1.3 fold with Apo-bLf and Fe-bLf respectively while the remaining, unused fragments (41 and $43 \mathrm{kDa}$ ) from the pro-caspase 


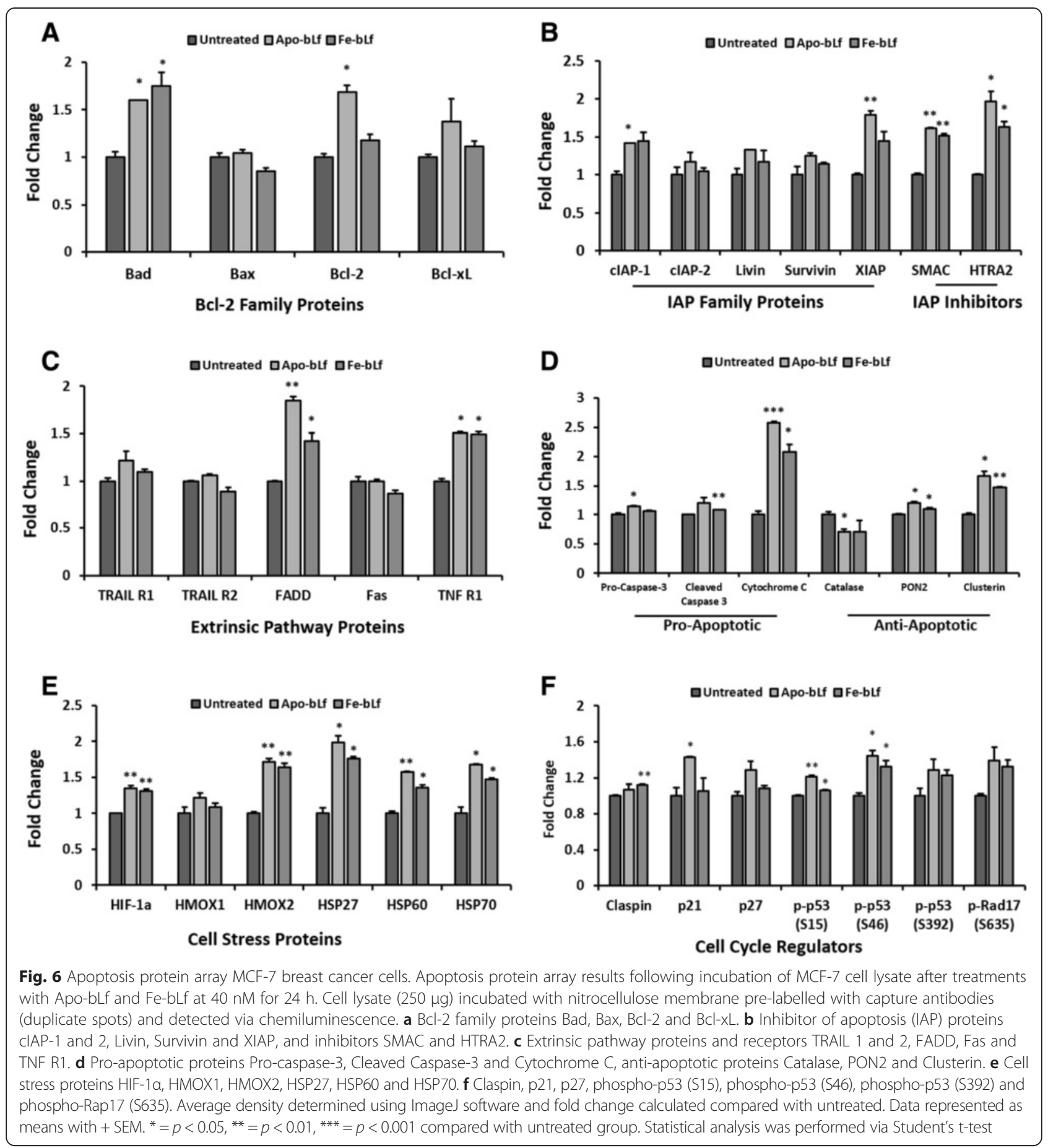

was increased to 7.7 and 7.5 fold respectively indicating large levels of cleavage. Furthermore, cleaved caspase-9 was increased by 2.6 and 2.5 fold with Apo-bLf and FebLf respectively. Analysis of effector caspase- 3 was then performed in MDA-MB-231 (Fig. 7c) and MCF-7 (Fig. 7d) cells. In MDA-MB-231 cells, a large decrease in procaspase-3 was observed with both Apo-bLf and Fe-bLf with expression reduced to 0.3 and 0.4 fold respectively of untreated cells. This was taken to indicate caspase cleavage and this was further confirmed by Western blot analysis of cleaved caspase-3 levels in MDA-MB-231 cells. Cleaved caspase- 3 levels increased by 2.1 fold in cells treated with Apo-bLf and slight increase by 1.3 fold in cells treated with Fe-bLf. In MCF-7 cells, pro-caspase-3 increased with both Apo-bLf (2.1 fold) and Fe-bLf (2.2 fold). Cleaved caspase-3 was relatively unchanged in Fe- 


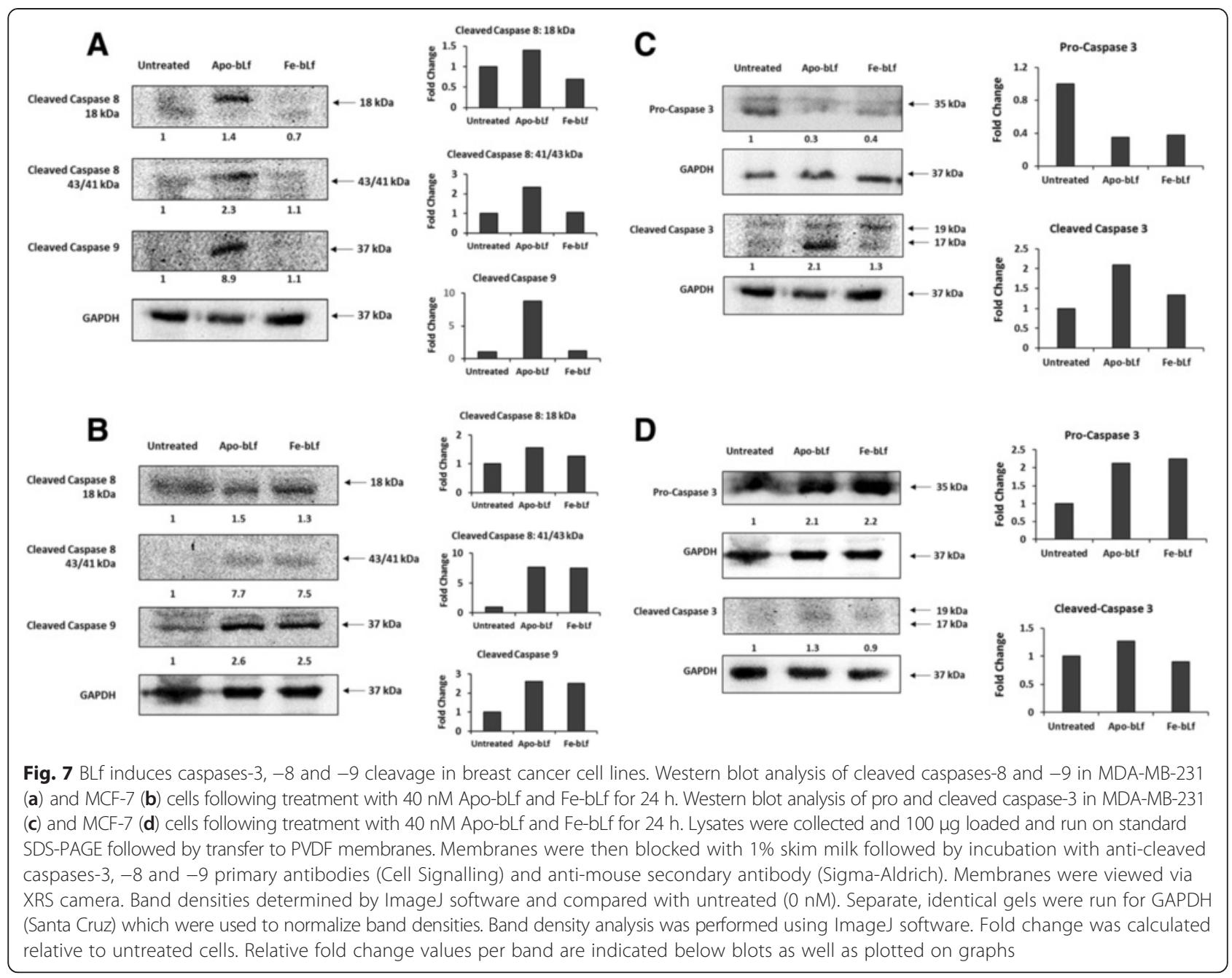

bLf and a slight increase observed with Apo-bLf (1.3 fold) (Fig. 7d).

\section{BLf treatment leads to time and dose dependent down-regulation of survivin protein expression in both MDA-MB-231 and MCF-7 cells}

As survivin is a key IAP protein in cancer and significant reduction was observed in MDA-MB-231 cells in apoptotic arrays following $24 \mathrm{~h}$ treatments (Fig. 5b), Western blotting was performed on a greater concentration range for $48 \mathrm{~h}$ in each cell line. Cells were treated with ApobLf and Fe-bLf at 20, 30 and $40 \mathrm{nM}$ and cell lysates were blotted for survivin. Survivin was detected in both untreated lysates (Fig. 8). Survivin was greatly reduced in all treatment groups with reduction in MDA-MB-231 cells to 0.4 and 0.1 fold with $20 \mathrm{nM}$ Apo-bLf and Fe-bLf respectively. Survivin expression in MCF-7 cells was reduced to 0.5 and 0.3 fold with $20 \mathrm{nM}$ Apo-bLf and FebLf and to 0.1 fold that of untreated cells with $30 \mathrm{nM}$ Apo-bLf. No survivin was detected in MDA-MB-231 cells with either form of bLf at concentrations of 30 and
40 nM. Survivin was also not detected in MCF-7 cells after treatment with Fe-bLf at $30 \mathrm{nM}$ and both forms at $40 \mathrm{nM}$. Western blotting confirmed findings from the apoptotic array and provided important evidence for the mechanism of bLf in terms of its apoptosis-inducing potential.

\section{Discussion}

The presence of cell fragmentation (apoptotic bodies) in the images taken of cells after treatment indicates the strong cytotoxic effects of bLf in breast cancer cells. Increased growth inhibition and apoptosis have been demonstrated in native bLf treated colon, lung and squamous cancer cells in vivo $[18,19]$. Furthermore, our findings in 2008 demonstrated that mice fed with Fe-bLf showed greater reduction in Lewis lung carcinoma, B16 melanoma and EL4 lymphoma tumour size than identical mice fed with natural bLf or Apo-bLf [24]. Interestingly, in the present study, both human breast carcinoma derived cancer cells showed increased cytotoxicity with Apo-bLf compared with Fe-bLf particularly after 48 h. This enhanced 


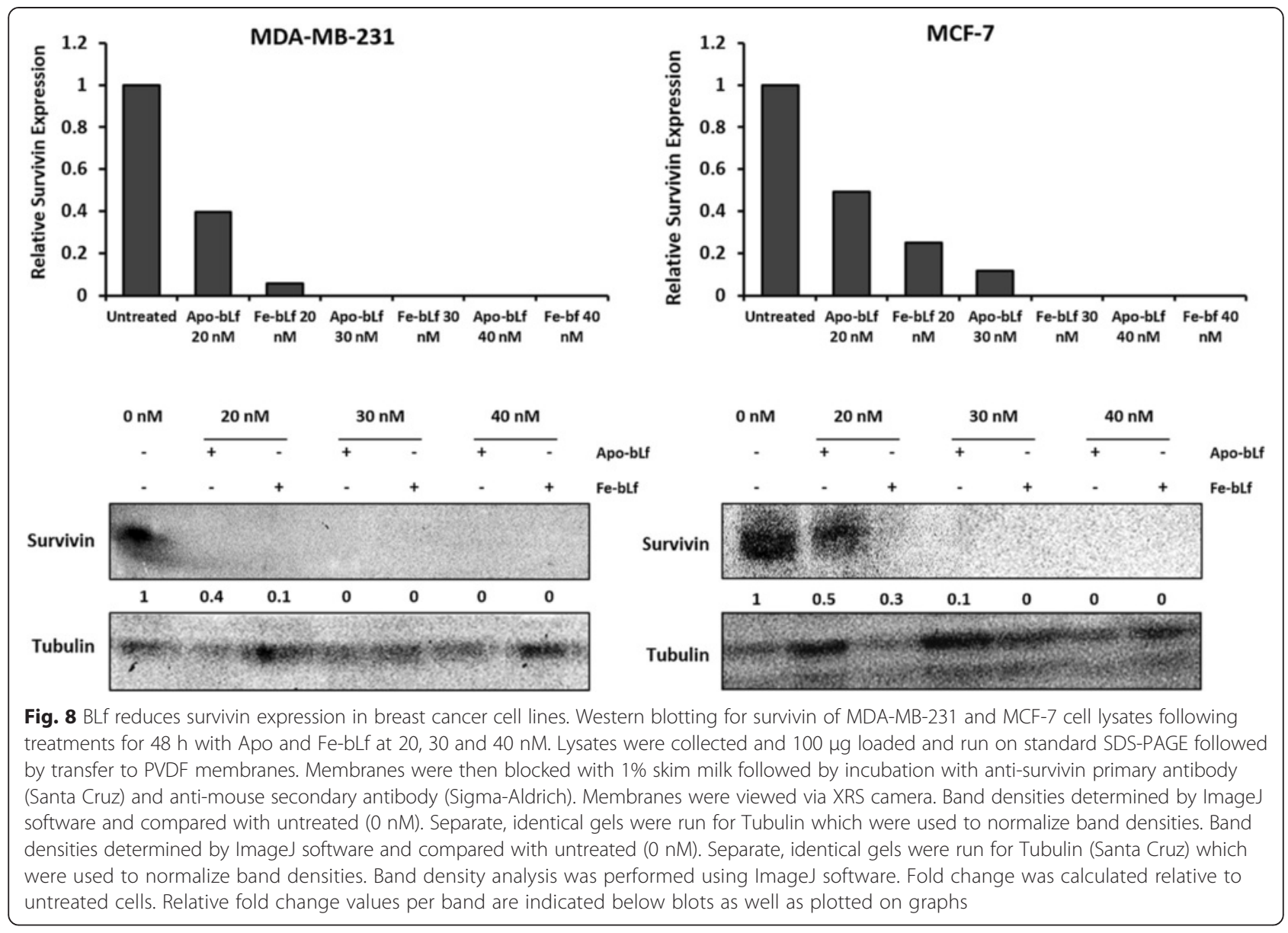

sensitivity of breast cancer cells to Apo-bLf may be tissue or cell line specific, and could possibly be related to iron metabolism in breast cancer cells with Apo-bLf playing a role in chelation and iron sequestering. Fe-bLf however was able to induce higher levels of apoptosis in MCF-7 cells in Annexin- $\mathrm{V}$ assays. It is also noteworthy to mention that native bLf has been reported to induce apoptosis and inhibit proliferation in T47D and HS578D breast cancer cell lines [21] however concentrations used were much higher $(0.125-125 \mu \mathrm{M}$, compared with $5-40 \mathrm{nM}$ in this study). While it is possible that the difference in dosage levels is cell specific, through published $[10,25]$ and unpublished work in our laboratory, we believe this isn't the case. We have observed similar cytotoxicity, growth inhibition and apoptosis effects of bLf forms at the nanomolar concentration range, over a range of cell lines obtained from human carcinomas of different origin such as colon (SW480 and Caco-2), liver (Hep3B) and melanoma (SKMEL-2 and SK-MEL-28). Moreover, The study in in T47D and HS578D breast cancer cell lines [21], was performed with native bLf (15-20\% $\mathrm{Fe}^{3+}$ saturated), thus the dosage level difference could be due to the modification of iron saturation levels of bLf given that the work we have performed is with Apo-bLf (iron free) and Fe-bLf (iron saturated). As it is vital to keep dose levels as low as possible, it is encouraging that modification of bLf in terms of iron saturation can allow such reduced dosage levels to be achieved. Moreover, due to its gut-enzyme resistant nature leading to increased bioavailability at tumour sites following oral administration [25], Fe-bLf has a better translation potential as a therapeutic. Encouragingly, no cytotoxicity was detected in normal mammary epithelial cells, MCF10-2A even after $48 \mathrm{~h}$ with either form of bLf tested. This is an important finding given the systemic toxicity often associated with traditional chemotherapeutic agents.

Invasion and migration assays indicated that both forms of bLf have the capacity to reduce these metastatic properties of both MDA-MB-231 and MCF-7 cells. Previously, native bLf has been shown to inhibit migration in breast cancer cells via scratch test assays [21]. We report here however that iron free and $>90 \%$ iron saturated bLf each have the capacity to reduce both migration and invasion in both MDA-MB-231 and MCF-7 cells. It is also prudent to note that Apo-bLf and Fe-bLf were used at concentration of 5 and $10 \mathrm{nM}$ compared with $12.5 \mu \mathrm{M}$ of native bLf in previous studies. In addition, it was observed that cells in untreated groups were able to fully pass through the pores whereas treated cells showed limited movement and 
were unable to completely pass through the pores. This possibly indicates that more time would be required for them to translocate and that bLf can reduce their movement capacity. This is an important and novel finding as migration and particularly invasion are key factors of cancer cells allowing them to travel through the body and create secondary cancer sites.

The ability of cancer cells to systematically avoid apoptotic mechanisms and signals is directly linked to their uncontrolled growth and proliferation subsequently allowing invasion and metastasis throughout the body [43]. We report here that both Apo-bLf and Fe-bLf significantly induce apoptosis in MDA-MB-231 and MCF-7 cells in a dose dependent manner. Apoptosis induced by bLf has been reported in several instances via both the extrinsic and intrinsic pathways [7, 20, 22, 23, 44]. Furthermore apoptosis was reported in two human breast cancer cell lines (different to the two cancer cell lines used in the present study) following native bLf treatment [21]. BLf has been shown to up-regulate the sensitivity of extrinsic pathway death receptor Fas in the colon mucosa of azoxymethane-induced colon tumour bearing rats [22] as well as up-regulation of the active forms of both caspase- 3 and -8 after treatments with bLf [23]. In addition, studies have also reported that bLf reduces the levels of intrinsic protein Bcl-2 in stomach cancer cells [20] as well as caspase-3 cleavage in squamous cell carcinoma [44]. In line with these findings, we report here that in MDA-MB-231 cells, Bcl-2 expression is reduced with Apo-bLf as is Pro-caspase-3, indicating possible cleavage (Fig 5a \& d) which was confirmed via Western blotting (Fig 7c).

Lactoferricin, a peptide derived from lactoferrin has also demonstrated increased apoptosis via the intrinsic pathway in leukemic and breast carcinoma cells by activating caspases- 3 and -9 but not caspase- $8[45,46]$. However, it was since shown that lactoferricin induces apoptosis in B-lymphoma in a caspase-independent fashion [47] and shown to induce apoptosis and activate caspases-3, -7 , -8 and -9 in gastric cancer thus implying that lactoferricins activity may be tissue/cell specific [48]. This appears to be possible in the case of the current study as MDA-MB-231 and MCF-7 appear to have distinct differences in the apoptotic factors activated following incubation with Apo-bLf and Fe-bLf.

It is apparent that bLf-induced apoptosis is higher in MCF-7 cells as observed through Annexin- $\mathrm{V}$ and by the levels of apoptotic molecule modulation determined via apoptotic array including cell stress proteins and cell cycle regulators. It may be possible that higher concentrations of bLf may induce similar level of apoptosis in MDA-MB-231 cells. A possible cause for this difference in behaviour may be due to the p53 status in the cell lines. MDA-MB-231 cells and MCF-7 cells differ in their p53 status with MDA-MB-231 cells harbouring a p53 mutation while MCF-7 are wild type. Differences in p53 modulation were observed in the apoptotic array with increases in phospho-p53 at serine 15 and 46 was observed with both Apo-bLf and Fe-bLf in MCF-7 cells while this was not observed in MDA-MB-231 cells. In fact, the opposite was observed in MDA-B-231 cells with all three p53 phosphorylation sites studies being downregulated following both Apo-bLf and Fe-bLf treatments. Given the complexity and importance of the p53 mechanism, extensive investigation into this finding could prove very interesting.

Survivin is a major inhibitor of apoptosis protein (IAP) acting in part by blocking the effect of caspases-3, -7 and -9 to allow cell evasion of apoptosis [1-3]. The role of native bLf, and its forms containing different levels of iron in targeting survivin expression in cancer cells is yet to be fully elucidated. More recently, we have reported that native bLf downregulates survivin gene expression in SW480 colon cancer cells [7], and Fe-bLf nanoformulation targets survivin to kill colon cancer stem cells [41] Here however it was found that MDA-MB-231 cells showed highly significant decreases in survivin protein expression levels, as well as strong increases in IAP inhibitors SMAC/DIABLO and HTRA2. SMAC/DIABLO was increased with Fe-bLf and HTRA2 was increased with both Apo-bLf and Fe-bLf. Furthermore, SMAC and HTRA2 were also upregulated in MCF-7 cells with both Apo-bLf and Fe-bLf. Both SMAC and HTRA2 inhibit IAPs by binding to them allowing caspase activation during apoptosis [49]. Western blot analysis of initiator caspases- 8 and -9 as well as effector caspase- 3 in MDAMB-231 cells revealed large increases in cleavage of all three caspases, predominantly with Apo-bLf. This was in line with apoptosis levels determined via Annexin-V Fluos staining. The largest increase in caspase cleavage in MDAMB-231 cells was with Apo-bLf in caspase-9 with an increase greater than 8-fold. This is consistent with the reduction in survivin given that survivin is known to bind and inhibit caspase-9 cleavage [50,51]. Thus, apoptosis in MDA-MB-231 cells appears predominately through the modulation and suppression of IAPs, and increased activity of IAP inhibitors (Fig 9). It was also observed that cleaved caspases- 8 and -9 were increased in MCF- 7 cells following both Apo-bLf and Fe-bLf indicating that the increases observed in the IAP inhibitors could be contributing to the activation of these caspases.

Survivin expression was significantly reduced by bLf treatments at the protein level in both cell lines. Most notably, this is the first report of bLf reducing survivin in breast cancer cells and confirms our earlier findings in colon cancer cells. Both Apo-bLf and Fe-bLf have the capacity to reduce survivin protein expression demonstrated via Western blotting and protein array. Survivin 

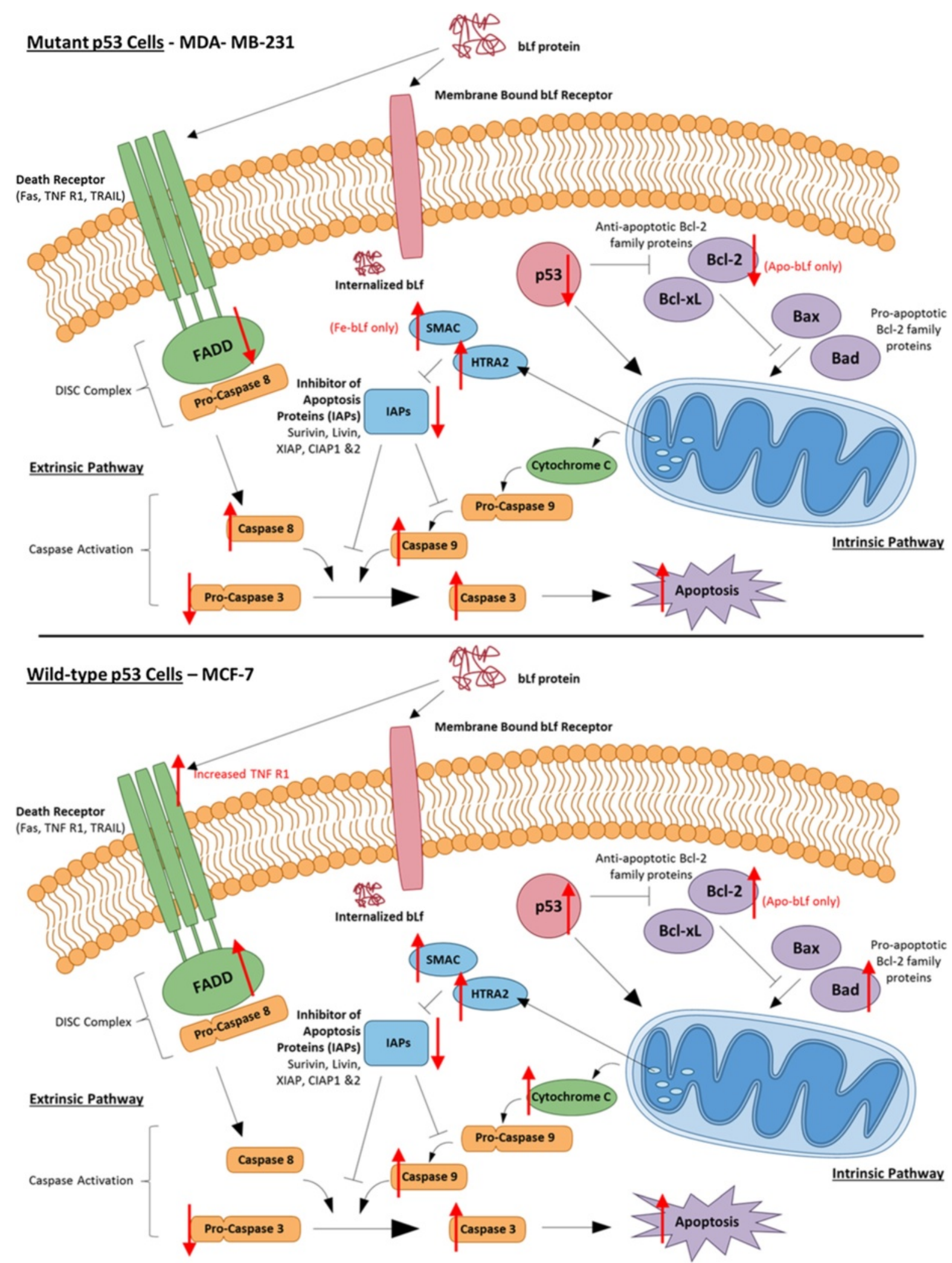

Fig. 9 (See legend on next page.) 
(See figure on previous page.)

Fig. 9 Apoptotic mechanisms in MDA-MB-231 and MCF-7 cells following treatment with Apo-bLf and Fe-bLf. BLf is internalized by membrane bound receptors such as Lf receptors via receptor mediated endocytosis. Once internalized, bLf modulates various apoptotic molecules as indicated by the red arrows. This modulation is cell specific as well as bLf form specific as some molecules are only activated or inhibited by one form of bLf

downregulation was shown after $48 \mathrm{~h}$ in both cancer cell lines (Fig. 8) and after $24 \mathrm{~h}$ in MDA-MB-231 cells (Fig 5b). As compared to normal cells, survivin is overexpressed in almost all cancer types and considered a validated target for anti-cancer therapies [52], thus bLf shows great potential for this role. It is important to note that despite a number of survivin inhibitors being tested in clinical trials, none have passed this phase due to their toxicity issues where bLf has a proven safety profile $[25,30,41]$.

Future investigations into the efficacy of Apo-bLf and Fe-bLf in in vivo models are of vital importance. Ideally, oral delivery is the preferred administration route due to the relative ease and patient compliance. Clinical trials in patients with colorectal polyps revealed a preventative potential of native bLf delivered daily $(3.0 \mathrm{~g})$ for 12 months $[53,54]$. Furthermore, native bLf delivered in mouse and rat diet in cancer treatment models revealed reduction in tumour sizes in colon, esophageal, lung and $[24,55]$. In addition, orally delivered Fe-bLf has been shown to augment the effects of traditional chemotherapeutics in breast and colon cancer models [24, 27]. These studies indicate that orally delivered bLf is a therapeutically viable delivery route. To further enhance the absorption and delivery of bLf, we have also reported the successful inhibition of xenograft tumours via oral delivery of nanoformulated bLf. Ceramic core, Fe-bLf encapsulated nanoparticles coated with chitosan and alginate were developed and delivered to mice bearing Caco-2 (colon cancer) xenograft tumours [25]. Tumour retardation was observed with successful delivery of Fe-bLf to the tumour site indicating that oral delivery of nanoformulated bLf may be a successful strategy to enhance absorption in the gut. Moreover, nanoformulated Fe-bLf was found to be highly significantly effective when given orally, as a pretreatment. This strategy could be applied to other cancers including breast cancer.

\section{Conclusions}

In conclusion, it is reported that while both Apo-bLf and Fe-bLf showed anti-tumourigenic properties, ApobLf demonstrated an enhanced effect over Fe-bLf at inducing cytotoxicity and reducing invasion and migration in both cancer cell lines while Fe-bLf was more effective at inducing apoptosis in MCF-7 cell lines. This is a particularly novel finding given that iron saturated bLf has been found to be more efficient in colon cancer models in previous studies. Given that no significant cytotoxicity was detected in normal MCF-10-2A cells our findings highlight that bLf has great potential as a safe anti- cancer agent with cell-type specific effects. Furthermore, the modulation of different apoptotic molecules between MDA-MB-231 and MCF-7 cell highlights a multifunctional role of bLf in breast cancer cells. While it is evident that bLf ultimately induces caspase cleavage and finally apoptosis in both cancer cell lines, it is apparent that different pathways are being activated in the process, namely the IAP pathway in MDA-MB-231 cells and the p53 pathway in MCF-7 cells (Fig. 9).

\section{Competing interests}

The authors declare that they have no competing interests.

\section{Authors' contributions}

Conception and Design: RKK, JRK and JAG; Acquisition of data: JAG; Analysis and interpretation of data: all authors; Manuscript drafting: JAG and RKK; Manuscript revising: all authors; Final approval of this version: all authors. All authors read and approved the final manuscript.

\section{Acknowledgements}

The work was funded by Australia-India Strategic Research Fund (AISRF, BF 030016). The financial support for postgraduate fellowship for J. Gibbons from BioDeakin, the Institute for Frontier Materials and the Faculty of Health, Deakin University is gratefully acknowledged.

Received: 3 February 2015 Accepted: 15 May 2015

Published online: 22 May 2015

\section{References}

1. Mita AC, Mita MM, Nawrocki ST, Giles FJ. Survivin: key regulator of mitosis and apoptosis and novel target for cancer therapeutics. Clin Cancer Res. 2008;14:5000-5.

2. Asanuma H, Torigoe T, Kamiguchi K, Hirohashi Y, Ohmura T, Hirata K, et al. Survivin expression is regulated by coexpression of human epidermal growth factor receptor 2 and epidermal growth factor receptor via phosphatidylinositol 3-kinase/AKT signaling pathway in breast cancer cells. Cancer Res. 2005;65:11018-25.

3. Samarasinghe RM, Gibbons J, Kanwar RK, Kanwar JR. Nanotechnology based platforms for survivin targeted drug discovery. Expert Opin Drug Discov. 2012;7:1083-92.

4. Baker EN, Baker HM. Molecular structure, binding properties and dynamics of lactoferrin. Cell Mol Life Sci. 2005;62:2531-9.

5. ligo M, Alexander DB, Long N, Xu J, Fukamachi K, Futakuchi M, et al. Anticarcinogenesis pathways activated by bovine lactoferrin in the murine small intestine. Biochimie. 2009;91:86-101.

6. Gibbons JA, Kanwar RK, Kanwar JR. Lactoferrin and cancer in different cancer models. Front Biosci (Schol Ed). 2011;3:1080-8.

7. Kanwar RK, Kanwar JR. Immunomodulatory lactoferrin in the regulation of apoptosis modulatory proteins in cancer. Protein Pept Lett. 2013;20:450-8.

8. Kuhara T, Yamauchi K, Tamura Y, Okamura H. Oral administration of lactoferrin increases NK cell activity in mice via increased production of IL-18 and type I IFN in the small intestine. J Interferon Cytokine Res. 2006;26:489-99.

9. Thotathil Z, Jameson MB. Early experience with novel immunomodulators for cancer treatment. Expert Opin Investig Drugs. 2007;16:1391-403.

10. Ebrahim F, Shankaranarayanan JS, Kanwar JR, Gurudevan S, Krishnan UM, Kanwar RK. Identification of unprecedented anticancer properties of high molecular weight biomacromolecular complex containing bovine lactoferrin (HMW-bLf). PLoS One. 2014;9:e106568.

11. EFSA Panel on Dietetic Products NaAN. Scientific opinion on bovine lactoferrin. EFSA Journal. 2012;10:2701-27. 
12. Agency Response Letter GRAS Notice No. GRN 000077 [http://www.fda.gov/ Food/IngredientsPackagingLabeling/GRAS/Noticelnventory/ ucm154188.htm].

13. ligo M, Kuhara T, Ushida Y, Sekine K, Moore MA, Tsuda H. Inhibitory effects of bovine lactoferrin on colon carcinoma 26 lung metastasis in mice. Clin Exp Metastasis. 1999;17:35-40.

14. Tsuda H, Sekine K, Takasuka N, Toriyama-Baba H, ligo M. Prevention of colon carcinogenesis and carcinoma metastasis by orally administered bovine lactoferrin in animals. Biofactors. 2000;12:83-8.

15. Ushida Y, Sekine K, Kuhara T, Takasuka N, ligo M, Maeda M, et al. Possible chemopreventive effects of bovine lactoferrin on esophagus and lung carcinogenesis in the rat. Jpn J Cancer Res. 1999;90:262-7.

16. Masuda C, Wanibuchi H, Sekine K, Yano Y, Otani S, Kishimoto T, et al. Chemopreventive effects of bovine lactoferrin on N-butyl-N-(4-hydroxybutyl) nitrosamine-induced rat bladder carcinogenesis. Jpn J Cancer Res. 2000;91:582-8.

17. Yamada Y, Sato R, Kobayashi S, Hankanga C, Inanami O, Kuwabara M, et al. The antiproliferative effect of bovine lactoferrin on canine mammary gland tumor cells. J Vet Med Sci. 2008;70:443-8.

18. Rodrigues L, Teixeira J, Schmitt F, Paulsson M, Mansson HL. Lactoferrin and cancer disease prevention. Crit Rev Food Sci Nutr. 2009;49:203-17.

19. Freiburghaus $C$, Janicke $B$, Lindmark-Mansson H, Oredsson SM, Paulsson MA. Lactoferricin treatment decreases the rate of cell proliferation of a human colon cancer cell line. J Dairy Sci. 2009;92:2477-84.

20. Xu XX, Jiang HR, Li HB, Zhang TN, Zhou Q, Liu N. Apoptosis of stomach cancer cell SGC-7901 and regulation of Akt signaling way induced by bovine lactoferrin. J Dairy Sci. 2010;93:2344-50.

21. Duarte DC, Nicolau A, Teixeira JA, Rodrigues LR. The effect of bovine milk lactoferrin on human breast cancer cell lines. J Dairy Sci. 2011;94:66-76.

22. Fujita K, Matsuda E, Sekine K, ligo M, Tsuda H. Lactoferrin modifies apoptosis-related gene expression in the colon of the azoxymethane-treated rat. Cancer Lett. 2004;213:21-9.

23. Fujita K, Matsuda E, Sekine K, ligo M, Tsuda H. Lactoferrin enhances Fas expression and apoptosis in the colon mucosa of azoxymethane-treated rats. Carcinogenesis. 2004;25:1961-6.

24. Kanwar JR, Palmano KP, Sun X, Kanwar RK, Gupta R, Haggarty N, et al. 'Iron-saturated' lactoferrin is a potent natural adjuvant for augmenting cancer chemotherapy. Immunol Cell Biol. 2008;86:277-88.

25. Kanwar JR, Mahidhara G, Kanwar RK. Novel alginate-enclosed chitosan-calcium phosphate-loaded iron-saturated bovine lactoferrin nanocarriers for oral delivery in colon cancer therapy. Nanomedicine (Lond). 2012.

26. Troost FJ, Steijns J, Saris WH, Brummer RJ. Gastric digestion of bovine lactoferrin in vivo in adults. The Journal of nutrition. 2001;131:2101-4.

27. Sun X, Jiang R, Przepiorski A, Reddy S, Palmano KP, Krissansen GW. "Iron-saturated" bovine lactoferrin improves the chemotherapeutic effects of tamoxifen in the treatment of basal-like breast cancer in mice. BMC Cancer. 2012;12:591.

28. Burrow H, Kanwar RK, Kanwar JR. Antioxidant enzyme activities of iron-saturated bovine lactoferrin (Fe-bLf) in human gut epithelial cells under oxidative stress. Med Chem. 2011;7:224-30.

29. Burrow H, Kanwar RK, Mahidhara G, Kanwar JR. Effect of Selenium-Saturated Bovine Lactoferrin (Se-bLF) on antioxidant enzyme activities in human gut epithelial cells under oxidative stress. Anticancer Agents Med Chem. 2011;11:762-71.

30. Samarasinghe RM, Kanwar RK, Kanwar JR. The effect of oral administration of iron saturated-bovine lactoferrin encapsulated chitosan-nanocarriers on osteoarthritis. Biomaterials. 2014;35:7522-34.

31. Tsuda H, Kozu T, linuma G, Ohashi Y, Saito Y, Saito D, et al. Cancer prevention by bovine lactoferrin: From animal studies to human trial. Biometals. 2010;23:399-409.

32. Singh PK, Parsek MR, Greenberg EP, Welsh MJ. A component of innate immunity prevents bacterial biofilm development. Nature. 2002;417:552-5.

33. Gauthier JD, Vasta GR. Inhibition of in vitro replication of the oyster parasite Perkinsus marinus by the natural iron chelators transferrin, lactoferrin, and desferrioxamine. Dev Comp Immunol. 1994;18:277-86.

34. Arnold RR, Cole MF, McGhee JR. A bactericidal effect for human lactoferrin. Science. 1977;197:263-5.

35. Oram JD, Reiter B. Inhibition of bacteria by lactoferrin and other iron-chelating agents. Biochim Biophys Acta. 1968;170:351-65.
36. Jiang XP, Wang F, Yang DC, Elliott RL, Head JF. Induction of apoptosis by iron depletion in the human breast cancer MCF-7 cell line and the 13762NF rat mammary adenocarcinoma in vivo. Anticancer Res. 2002;22:2685-92.

37. Marques $\mathrm{O}$, da Silva BM, Porto $\mathrm{G}$, Lopes C. Iron homeostasis in breast cancer. Cancer Lett. 2014;347:1-14.

38. Chekhun VF, Lukyanova NY, Burlaka CA, Bezdenezhnykh NA, Shpyleva SI, Tryndyak VP, et al. Iron metabolism disturbances in the MCF-7 human breast cancer cells with acquired resistance to doxorubicin and cisplatin. Int J Oncol. 2013:43:1481-6.

39. Torti SV, Torti FM. Cellular iron metabolism in prognosis and therapy of breast cancer. Crit Rev Oncog. 2013;18:435-48.

40. Heath JL, Weiss JM, Lavau CP, Wechsler DS. Iron deprivation in cancer-potential therapeutic implications. Nutrients. 2013:5:2836-59.

41. Kanwar JR, Mahidhara G, Roy K, Sasidharan S, Krishnakumar S, Prasad N, et al. Fe-bLf nanoformulation targets survivin to kill colon cancer stem cells and maintains absorption of iron, calcium and zinc. Nanomedicine (Lond). 2015;10(1):35-55.

42. Lonnerdal B, Jiang R, Du X. Bovine lactoferrin can be taken up by the human intestinal lactoferrin receptor and exert bioactivities. J Pediatr Gastroenterol Nutr. 2011:53:606-14.

43. Hanahan D, Weinberg RA. The hallmarks of cancer. Cell. 2000;100:57-70.

44. Sakai T, Banno Y, Kato Y, Nozawa Y, Kawaguchi M. Pepsin-digested bovine lactoferrin induces apoptotic cell death with JNK/SAPK activation in oral cancer cells. J Pharmacol Sci. 2005:98:41-8.

45. Mader JS, Salsman J, Conrad DM, Hoskin DW. Bovine lactoferricin selectively induces apoptosis in human leukemia and carcinoma cell lines. Mol Cancer Ther. 2005;4:612-24.

46. Wang S, Tu J, Zhou C, Li J, Huang L, Tao L, Zhao L. The effect of Lfcin-B on non-small cell lung cancer $\mathrm{H} 460$ cells is mediated by inhibiting VEGF expression and inducing apoptosis. Arch Pharm Res. 2014.

47. Furlong SJ, Mader JS, Hoskin DW. Bovine lactoferricin induces caspaseindependent apoptosis in human B-lymphoma cells and extends the survival of immune-deficient mice bearing B-lymphoma xenografts. Exp Mol Pathol. 2010;88:371-5.

48. Pan WR, Chen PW, Chen YL, Hsu HC, Lin CC, Chen WJ. Bovine lactoferricin B induces apoptosis of human gastric cancer cell line AGS by inhibition of autophagy at a late stage. J Dairy Sci. 2013;96:7511-20.

49. Verhagen AM, Silke J, Ekert PG, Pakusch M, Kaufmann H, Connolly LM, et al. HtrA2 promotes cell death through its serine protease activity and its ability to antagonize inhibitor of apoptosis proteins. J Biol Chem. 2002;277:445-54.

50. Mahdavi M, Davoodi J, Zali MR, Foroumadi A. Concomitant activation of caspase-9 and down-regulation of IAP proteins as a mechanism of apoptotic death in HepG2, T47D and HCT-116 cells upon exposure to a derivative from 4-aryl-4H-chromenes family. Biomed Pharmacother. 2011;65:175-82.

51. Wrzesien-Kus A, Smolewski P, Sobczak-Pluta A, Wierzbowska A, Robak T. The inhibitor of apoptosis protein family and its antagonists in acute leukemias. Apoptosis : an international journal on programmed cell death. 2004;9:705-15.

52. Kanwar RK, Cheung $\mathrm{CH}$, Chang JY, Kanwar JR. Recent advances in anti-survivin treatments for cancer. Curr Med Chem. 2010;17:1509-15.

53. Kozu T, linuma G, Ohashi $Y$, Saito $Y$, Akasu T, Saito D, et al. Effect of orally administered bovine lactoferrin on the growth of adenomatous colorectal polyps in a randomized, placebo-controlled clinical trial. Cancer Prev Res (Phila Pa). 2009:2:975-83.

54. ligo M, Alexander DB, Xu J, Futakuchi M, Suzui M, Kozu T, et al. Inhibition of intestinal polyp growth by oral ingestion of bovine lactoferrin and immune cells in the large intestine. Biometals. 2014;27:1017-29.

55. Tsuda H, Sekine K, Nakamura J, Ushida Y, Kuhara T, Takasuka N, et al. Inhibition of azoxymethane initiated colon tumor and aberrant crypt foc development by bovine lactoferrin administration in F344 rats. Adv Exp Med Biol. 1998:443:273-84 